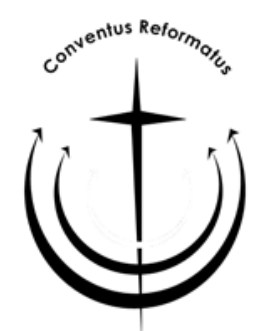

\title{
Calvin and the spiritual trends of his time: the uniqueness of the sixteenth-century protestant Reformation
}

\author{
B.J. van der Walt \\ School of Philosophy \\ Potchefstroom Campus \\ North-West University \\ POTCHEFSTROOM \\ E-mail: hannah@intekom.co.za
}

\begin{abstract}
Calvin and the spiritual trends of his time: the uniqueness of the sixteenth-century protestant Reformation

This article is of an exploratory nature, and it will try to answer the difficult question as to who Calvin really was - a man born 500 years ago who disliked self-disclosure. The main question to be investigated is which spiritual trends influenced Calvin's thinking. To arrive at an answer to this important question in Calvin research, the following steps will be taken. Firstly, a few misconceptions about who Calvin was will be argued. Secondly, attention is asked for the problems encountered in this kind of research. Thirdly, an overview of the different spiritual currents forming the backdrop of the sixteenth-century Reformation will be given. This will inter alia reveal the unique character of Calvin's own reformational endeavours. The last (fourth) section will summarise the results regarding the complex and decisive times in which Calvin lived and worked, and also indicate the uniqueness of the reformational endeavour of the sixteenth century.
\end{abstract}

\section{Opsomming}

Calvyn en die geestestromings van sy tyd: die uniekheid van sestiende-eeuse protestantse Reformasie

Hierdie oorsigtelik-verkennende artikel probeer die vraag beantwoord wie Calvyn werklik was - hy is reeds 500 jaar gelede gebore en het nie daarvan gehou om oor homself te skryf nie. Die hoofvraag is watter geestestromings sy denkontwikkeling 
beïnvloed het. Om 'n antwoord op hierdie fundamentele dog moeilike vraag in Calvynnavorsing te bied, sal die volgende stappe gevolg word. Eerstens word 'n paar mites oor wie Calvyn was, bespreek. Tweedens word die aandag gevra vir enkele probleme aan hierdie soort navorsing verbonde. Derdens word op die verskeidenheid geestestromings gelet wat die agtergrond of décor van die sestiende-eeuse Reformasie vorm. Die vierde gedeelte bevat 'n samevatting van navorsing oor hierdie komplekse dog beslissende epog en toon ten slotte aan wat die unieke van die reformatoriese beweging van die sestiende eeu was.

\section{Introduction}

This introduction will briefly state who Calvin really was and what the focus of the article as well as its nature will be.

\subsection{Who Calvin was}

This article is not of a biographical nature. Many new biographies of Calvin are available today (cf. Parker, 2007; Selderhuis, 2009). Because an icon like Calvin easily becomes a kind of super human being - an unofficially declaired saint! - the most obvious fact has to be stated right at the beginning, viz. that while acknowledging the fact that he was an exceptionally gifted person with influence up to the present-day, he still was an ordinary, fallible human being. Some of the myths associated to him to be argumented are the following.

\subsubsection{Not a supra-historical person}

In the first place he was not a supra-historical figure, but a man of his times, the sixteenth century.

It is wrong to regard Calvin, from pious motives, as many do, as sort of sixteenth century Melchizedek, a man without an origin. This would imply his growing up without the influences of his times. It would be simplistic to explain Calvin's thought merely as the result of extra-biblical influences. It would, however, be equally simplistic to think that he underwent no influences other than biblical ones. To presume that Calvin became a reformer because he was purely a Scriptural theologian is a confessional rather than a historical statement, because it leaves unanswered the important question as to which presuppositions Calvin held in reading the Scriptures. (Van der Walt, 1991:228.) 
Perhaps the work of Bouwsma (1988) is one of the best to read to convince one to see how thoroughly Calvin lived and thought in the sixteenth century.

\subsubsection{Not merely a biblical interpreter}

In the second place, because Calvin succeeded to explain the Bible in such a clear way, some of his followers regarded him as the reformer which only studied and explained the Bible and was not influenced either by other Christian or secular literature. Oberman, however, clearly states:

In the unfolding of his biblical theology and in building his institutions, Calvin used a whole range of authors from Augustine to Luther, from d'É taples to Budé, from Erasmus to Bullinger, and he reflected currents ranging all the way from Platonism to late medieval Scotism. (Oberman, 1994:153.)

Calvin's thought thus developed not only as a result of his intimate contact with the Bible, but also from his contact with other spiritual trends. He was, for example, constantly in live contact with the Roman Catholic Church on the one hand and the more radical trends (Anabaptists, Spiritualists, Anti-trinitarians and Libertinists) on the other hand (cf. Estep, 1986:13 ff.). This, quite apart from the possible influence by other contemporary currents of thought such as Humanism and the Renaissance. His contact with other reformers should also be remembered. Add to this his acquaintance with trends from the past such as Platonism (recurring in his time), Stoicism (likewise resurging in the sixteenth century) and the early church fathers (especially Augustine and Chrysostomos).

It is fascinating to see the development and formation of Calvin's thought from a dialogue - more properly a polilogue - with all the above-mentioned spiritual currents. Sound Calvin-study cannot, therefore, concentrate only on Calvin and the Scriptures. A study of his spiritual formation and development demands a far more comprehensive approach.

\subsubsection{Not merely a theologian}

The third misconception about Calvin's identity was the assumption that he was primarily a theologian. This, for example, can clearly be seen from the book by Niesel, originally published in German in 1938 and in English in 1980, as well as a recent reference work on Calvin, edited by Selderhuis (2008). A recent catalogue of a Dutch bookseller (July 2009) announced about 30 new books on Calvin - 
all of them theological works. Calvin did make a huge contribution to reformed theology, but he himself did not enjoy formal theological training (he studied the humanities and law). He, furthermore, called his own Institutes his Christian philosophy (philosophia Christiana). In contemporary terminology we would describe it as a (prescientific) Christian worldview and not as theology.

It is an unfortunate fact that in the past Calvin was primarily regarded, and also studied, as a theologian and not from a variety of other disciplines. However, when one follows the proceedings of the different European, South African and international Calvin Research Congresses, this narrow theological approach is gradually overcome to also include other important facets of Calvin's heritage.

\subsection{The focus of this contribution.}

It has to be kept in mind that prior to Calvin's conversion to Protestantism he was a Roman Catholic and enjoyed a thorough schooling from humanist scholars. The question is to what extent he could free himself from these earlier influences. Apart from this, the influence of various spiritual trends and people following his conversion, have to be investigated. Especially the formative years of the young Calvin (up to about 1536) have to be studied. One of the important studies to be consulted in this respect is the work of Ganoczy (first published in 1966 and translated into English in 1987).

This survey will, so to say, employ a wide-angle lens, while a next article will focus on the philosophical details. One first has to investigate the currents or spiritual trends in Calvin's time, before the details of specific types of philosophy, present within these trends, can be scrutinised.

A trend has to do with what kind of normativity a certain epoch accepts, while different types explain how thinkers view the ontological structures of reality. (Cf. Vollenhoven, 2005a:99-115; 2005b; 2005c: xxvii as well as Brill \& Boonstra, 2000:271, 401-408 for a detailed explanation of the distinction between trends and types as well as direction and structures.) A current, therefore, answers the question what ought to be, while a type answers the question what is. This article will focus on what kind of normativity guided the different spiritual trends or directions round about the sixteenth century. The next article's focus will be on the types of philosophies during those times and their possible influence on Calvin. 


\subsection{The nature of the article}

This investigation is in the first place not an example of "Kleinforschung", but a general survey. Secondly, in this updated version I am still relying on previous publications (cf. Van der Walt, 1979; 1991). I, nevertheless, hope that it will provide some guidance to newcomers in Calvin-research through a massive amount of literature and also confusion about who Calvin as thinker really was.

Before embarking on this task, the reader should first be warned about the problems associated with the pursuit of Calvin's intellectual pedigree.

\section{Problems encountered in this kind of research}

The Calvin-expert Wendel (1963) already warned in 1963 that tracking down the various (spiritual and philosophical) influences on Calvin's development will not be an easy task:

To meet this question with an answer which, if not definitive, would at least be precise enough in detail, clearly demands a meticulous comparison of all Calvin's writings with all the other works that might, directly or distantly, have determined his way of seeing things - a gigantic labour, not impossible in itself, but one that no one has yet had the courage and patience to undertake. (Wendel, 1963:359.)

What exactly are some of the stumbling blocks to be faced?

\subsection{Calvin himself is not of much help}

In the first place Calvin's own writings cannot help us much in tracing his intellectual pilgrimage. Oberman explains the problem by comparing Calvin with Luther:

Whereas Luther's persona looms large on every page of his work, Calvin is inclined to be so 'private' that it is difficult to discern the person behind the pen and to discover the emotional heartbeat behind his intellectual drive to grasp the mysteries of God and the world. (Oberman, 1994:114.)

Apart from the fact that Calvin himself did not leave behind enough clues as to what he read and from whom he learnt, he also did not present information concerning his presuppositions, logic or method of thinking (cf. Neuser, 1982:5). 


\subsection{The time gap}

In the second place Calvin lived and wrote about 450 years ago. It is a delicate enterprise today to distinguish between fact and fantasy in reconstructing especially the early stages (up to about 1536) in Calvin's intellectual development. In the light of the time gap, one can also ask whether Calvin's thought is still relevant in our contemporary world, facing totally different problems (cf. Klapwijk, 1994:92).

\subsection{Books are not sufficient sources}

Thirdly, when one studies the "beginnings" of Calvin, from puberty to adulthood (16 to 26 years of age), we should take into consideration that Calvin was not only influenced by the books he read (some of them still available to the modern researcher - cf. Ganoczy, 1969 and Ganoczy \& Müller, 1981), but by far more, his psychological, religious, political and social experiences.

\subsection{Two opposite extremes}

A next problem to be mentioned in tracing Calvin's development is the danger of extreme viewpoints. In spite of his having been a great reformer, Calvin was also a product of his past and his own time. However, his thought should not be reduced merely to the ideas of others. Then again, he may not, as some of his supporters insist on doing, be elevated above the matrix from which he grew and the climate in which he developed spiritually.

As will become evident, the research on Calvin's spiritual pedigree did not always succeed to escape an overemphasis to the one or other side. Oberman (1994:117) correctly says that up to the middle of the previous century many studies tried to describe Calvin as, for example, a thoroughgoing Augustinian, Platonist or Scotist. An awareness, however, gradually emerged that an original thinker like Calvin could not be called a schoolman. It may therefore be a better approach not to look for elements in which Calvin was still bound to tradition, but rather search for his uniqueness. This is the approach taken by, for instance, Klapwijk (1991). In this article about the religious direction of Calvin's thought I will show how Calvin indicated a new direction. The next article (about his type of philosophy) will, however, emphasise how he was still bound to the old.

\subsection{Calvin's thought reduced to one central idea}

This uniqueness - a fifth problem - should not be sought in one central idea governing Calvin's whole "system". 
Nauta (1976:76) indicated 30 years ago that the previous efforts to reduce Calvin's thinking to a single denominator (e.g. God's sovereignity, predestination, his glory or whatever) has proved not convincing. Twenty years later, Gamble (1994:106) regarded it necessary to stress again:

... most leading scholars today maintain that there is no single key to unlock the door of Calvin's theology. There is a consensus that there is more than one centrally important theme, or to continue the key analogy, that some keys open more doors than others.

Also Oberman $(1994: 117,127,152)$ rejects the idea of a central dogma or controlling principle in Calvin. He warns against a "pedigree pursuit" which transformed Calvin into a Platonist, Stoic, Scotist, nominalist, humanist or into the propagator of a single doctrine. Many themes (like the glory of God, the secret operation of the Spirit, the growth of his kingdom, the danger of idolatry, the strategy of Satan, etc.) can be regarded as cornerstones of Calvin's theology.

\subsection{Calvin not to be reduced to a mere intellectual}

As a conclusion it should be stated (we will return to this point at the end) that, in drawing Calvin's intellectual portrait, the intention is not to portray the real Calvin one-sidedly as a thinker. He was a human being, husband, father, pastor, teacher and much more; a historical person of flesh and blood. Oberman (1994:117) correctly reminds us that at decisive stages of his life Calvin responded not only to currents of thought, but also to religious needs, political challenges, social experiences and personal encounters. During 1525-1535 he even had to face the dangers of persecution, imprisonment and even the stake.

\subsection{Of vital importance}

In spite of all the stumbling blocks to be overcome, a clear insight into Calvin's intellectual formation is of vital importance. Three decades ago Nauta $(1976: 83,84)$ emphasised the need of more careful research on the sources and foundations of Calvin's thinking. The same point is re-emphasised by Neuser (1982:4-5), Saxer (1984:110 ff.) and Gamble (1994:109), who concludes his review of research in this area with the words: "We are still left ... with no consensus." It is evident that insight into Calvin's intellectual for- 
mation is a basic issue which may lead to a better understanding of all the other aspects of his thought.

We, therefore, have to look at the spiritual climate prior and during the time of Calvin's reformation.

\section{Spiritual trends before and during the time of the Reformation}

Explaining the intellectual décor of the fifteenth and sixteenth century is necessary because researches on Calvin often do not distinguish clearly between different types of humanism or between Humanism and the Renaissance. Something general has to be mentioned about the time of the Reformation before we restrict ourselves to a specific part of the canvas of this epoch, viz. its intellectual aspect.

\subsection{A period of crisis and change}

A few characteristics of this critical period have to be mentioned.

\subsubsection{Crises in every area of life}

Most of the readers will be aware of the crisis in ecclesiastical life during the end of the Middle Ages. Ordinary believers became deeply disturbed by the deformation and corruption in the Roman Catholic Church of the day.

A crisis had become apparent in several other spheres as well in the course of the late Medieval period of about 1350-1550 (cf. Reid, 1978:13-15). Apart from regular epidemics of the plague (the socalled Black Death) sweeping through Europe, the revolt of the farmers and the agrarian crises, it was especially the rapid urbanisation of that time which caused profound socio-economic changes.

Bouwsma summarises the situation clearly:

... the constant menace of famine and pestilence, urban disorders and endemic warfare in the countryside, incessant conflict among individuals, families, and social groups, a growing social mobility that left a substantial proportion of the urban population rootless and insecure, above all the terrible anxieties of life in which familiar conventions of a close and traditional human community had given way to a relentless struggle for survival in a totally unpredictable and threatening world (Bouwsma, 1975:17). 
Also Reid (1982:34 ff.) describes the rapid, radical, even revolutionary changes that occurred in Western Europe during two centuries (1300-1500) and concludes that "by 1500 Europe was a changed continent with a radically altered society".

It was therefore a very insecure age, especially for the growing urban population, because, apart from the financial crisis (inflation), they did not have the legal protection others were entitled to. They were not admitted to the guilds and they had no representation in urban government. After 500 years we today often forget that the reformers also lived in a time of political and religious persecution. For its influence on the life of an individual like Calvin see Oberman (1994:152 ff.).

\subsubsection{A widening of horizons}

Besides being classified as a period of crises and uncertainty in nearly every domain (religious, political, economic, social, etc.), this period is also characterised by unprecedented changes and a widening of horizons (cf. Klapwijk, 1991:123). The use of paper and the invention of the mobile printing press (by the middle of the fifteenth century) heralded a new era. The application of an old Chinese invention, the compass, made possible the "discovery" of America by Columbus and together with such voyages of discovery by other mariners (Bartholomew Diaz, Vasco da Gama, Amerigo Vespucci) enlarged the map of the world and broadened people's perspectives. In other areas of culture great changes also occurred. Only three years after Calvin's birth Copernicus launched his concept of a heliocentric system - and the current worldview was radically altered. Universities grew and schools were established; an early-capitalist commercial economy developed; a new merchant middle-class came into being; the farmers revolted against injustices; new spiritual currents of diverse character mushroomed; a renewal of art and learning was engendered by Humanism and Renaissance (Erasmus and Leonardo da Vinci). Apart from the religious and ecclesiastical changes, brought about by the sixteenth century Reformation, many novel things occurred. A new world was born!

It is understandable that, during such a transition period, the various spiritual trends which came into existence would pretend that their view of the world would offer new security and new direction. The protestant Reformation was thus not the only movement of the time intent on change. Together with many others it participated in innovation - and struggled with these others for supremacy. 
As indicated above (1.2) spiritual trends indicate different directions to be followed in life, because they uphold different viewpoints on what ought to be done. From what follows, it will become clear that the major difference between all the currents was that they accepted different guiding norms to give new direction in a situation of rapid change and great uncertainty.

\subsection{An overview of Western intellectual history}

According to Vollenhoven (2005a:29, 73; and 2005b for the English) the history of Western thought can be divided into a period of presynthetic thought (antiquity), synthetic thought (patristic and medieval thought) and post- or antisynthetic thought (modern and contemporary philosophy). Synthetic thought can be divided into a first synthesis (early Christian), a second synthesis (Medieval) and a third synthesis. The period of growth, flowering and decline of medieval thought is succeeded by the third synthesis (fifteenth century). It is especially this period, together with what can be regarded as the "prelude to the modern epoch" which needs our attention.

In order to complete the picture, we should also have a look at late medieval thought. The fact that this is not done, does not mean that we should go along with the idea that it was an insignificant period. The reformers - especially Martin Luther - cannot be understood properly without knowledge of, nominalism, dominant in late medieval thought (cf. Oberman, 1967; 1974a; 1974b). Because of limited space, this period will not be dealt with in this article.

\subsection{Third synthesis: pre-Reformation and "Christian" humanism}

In general this period is characterised by boredom with medieval culture. An anti-scholastic tendency is thus the prevalent mode. This intention could have been evaluated positively were it not for the way in which the various thinkers sought to realise it. They wanted to revive the patristic mode of synthetic thought. As a result of their disgust with the present, they wanted to return to an earlier period, to rejuvenate that period. A specific period in the history of Western culture cannot, however, be recalled and repeated at will - the clock of history cannot be turned back.

The two most important currents during this period were the preReformation (originating in England) and the earlier (synthetic or Christian) humanism (originating in Italy). The pre-Reformation, featuring men like Wycliffe and Hus, is reasonably well-known to us (cf. Ashley, 1962; Oberman, 1966). 


\subsubsection{Christian humanism}

Early (synthetic or Christian) Humanism has to be explained so that one does not confuse it with other types of Humanism. It is not the same trend as the later type of Humanism (cf. 3.6.1), which thought anti-synthetically (a subsidiary trend during the prelude to the modern epoch). Humanism in this case also does not mean what contemporary Christians understand by the term.

Vollenhoven's distinction between different types of humanism is important in the light of this confusion - also when scholars debate the influence of "humanism" on Calvin. Gamble (1994:98), for instance, discusses the divergent viewpoints on what humanism at the time of Calvin was (held by, for instance, McGrath and Augustijn). $\mathrm{He}$ concludes that this trend needs to be clearly defined before its influence on Calvin can be determined.

Yost (1965:iv) defines Christian humanism in the following terms:

... this study defines Christian humanism as the religious education movement during the late fifteenth and early sixteenth centuries which strove to achieve religious and ecclesiastical reform through a rebirth of the moralistic Christianity of antiquity.

This kind of humanism was primarily a pedagogical movement which did not study philosophy for its own sake, but for its practical applicability in education. Kristeller (1953:86) mentions two other characteristics, namely interest in classical philosophy and rhetoric.

It is, furthermore, interesting that these Christian humanists reintroduced the concept of a Christian philosophy - a term which was also used later by Calvin to indicate his thought (cf. Bohatec, 1950:251; Reuter, 1963:53; Partee, 1974; 1977:2-12).

\subsubsection{The difference between the two currents}

The difference between the pre-Reformation and Christian humanism is to be found in the fact that whereas both reached back to early Christian patristic thought, the representatives of the preReformation emphasised the scriptural aspect of early Christian thought (or first synthesis), whereas early Humanism was fascinated by the fact that the early Christian thinkers could be Romans as well. This type of humanism regarded human dignity and the intellectual, moral and religious abilities and needs of man as central and strived to find its ideal image in the Roman Republic (cf. Oberman, 1975). 
While the thinkers of the pre-Reformation and early Humanism thus both strove to reanimate the past and thus erred in the same way (repristination), there was an important difference in emphasis. The former intended to return to the Christian element in the synthetic thought of the patres and the latter to the roman or pagan element. In this respect the two trends were in a religious sense diametrically opposed. (The third synthesis was already a transitional phase to the modern anti-synthetic thought.)

\subsubsection{The lesson learned from their failure}

The value of these trends, however, resides in the fact that they kindled renewed interest in the great figures from the early Christian period, such as Augustine. Seeing that roman philosophy (with which early Humanism was concerned) is characterised particularly by stoic philosophy, the third synthesis also led to the reanimation of thinkers like Cicero and Seneca. As will be indicated later, Calvin was particularly attracted to this school of thought.

Humanist thinkers such as Dante (1265-1321) and Petrarch (13041374) as well as men from the circle of the pre-Reformation such as Bradwardine (d. 1349), Wycliffe (d. 1384) and Hus (d. 1415), however, vainly tried to reanimate the patristic thought, seeing that it did not fit into their times any more.

Petrarch tried to explain the disappointment over the fact that the reaching back to Augustine's ideas failed by maintaining that the famous bishop of Hippo was a Roman, while Petrarch himself was not a pure Roman any more, as the original inhabitants of Italy had in the meantime mixed with germanic groups.

As the sixteenth century reformers later realised, the pre-Reformation currents also failed, mainly because the repristinating tendency prevented them from seeing that real religious conversion is not the same as a return to an earlier historical epoch.

\subsection{The beginning of the modern epoch}

The great movement of synthetic thought (prepared in JudaeoHellenistic thought, originated in the early Christian milieu of emperors and church fathers, worked out scholastically during the medieval period and pedagogically and religiously refreshed by early Humanism and the pre-Reformation respectively) eventually came to an end at the fifteenth century. This does not mean that synthetic 
thought has ceased to be, but it was no longer the dominant trend within Western thought.

Our interest now focuses on the period of the sixteenth century, within which the Reformation fell, and which can be indicated as the beginning of modern anti-synthetic thought. Anti-synthetic leftist or secular and rightist or Christian thinking indicated different normative directions - a tendency already starting during the third synthesis. However, as at the beginning of each new epoch, the old was still functioning, so that apart from an anti-synthetic left and right, a third current, viz. the continuation of synthetic thought has to be distinguished.

\subsection{Continuation of synthetic thought}

Seeing that this trend does not belong to the main trend of the modern era, the main divisions are merely mentioned without any further particulars being given. A division into three categories is possible as a result of the fact that some thinkers were oriented towards early Humanism, some towards the Middle Ages and a third group towards the pre-Reformation. In each of these groupings synthetic thought can be traced in both Roman Catholic and Protestant milieu.

In the second group (oriented towards medieval philosophy) the growing authority of Thomas Aquinas appears from the fact that, according to a papal decree of Pius $V$ in 1567, he was declared as the fifth doctor ecclesiae. Men such as Franciscus Vittoria, Melchior Cano and Franciscus Suarez (d. 1617) contributed a great deal to the resurgence of Thomism. The Summa theologiae and other writings by Thomas Aquinas eventually became the recognised basis for the theological training in all Roman Catholic countries. Gründler (1961:1-12) has indicated the influence of this revived thomistic thought also on the protestant thought of the time. (This influence continued up to the twentieth century in the theologies of e.g. Bavinck and Schilder; cf. Bril \& Boonstra, 2000:389, 391.)

\subsection{Secular antisynthetic thought}

Three different trends can be distinguished within secular antisynthetic thought, viz. later or anti-synthetic Humanism, the Renaissance and, in the third instance, a link between the two (cf. Vollenhoven, 2005a:74-79; and 2005b for an English version). A brief look at each one of them follows. 


\subsubsection{Humanism}

The type of Humanism encountered shortly before and during the Reformation agreed with earlier "Christian" humanism that (as a result of disillusionment with the present) it wanted to return to the past for solutions of its pedagogical problems. These humanists tried to idealise the beautiful ideals of their predecessors (cf. Oberman, 1975:xii). Elsewhere Oberman says:

This pedagogical concern is so much one of the characteristics of what we call the initia reformationis, that humanism is not only the context in which the Reformation could flower, but, at least for a time, it was also to be an inseparable partner through the inner association of the studia humanitatis with the concern for religious sanctification. (Oberman, 1974a:69.)

This type of humanism, however, differed from early Humanism in the sense that the early period intended for imitation was not the patristic (first synthesis) but Greek and Roman antiquity - a clear proof of its leftist anti-synthetic character. The ideas of a man such as Boccaccio (d.1365) illustrate this clearly. He did not ask, as Petrarch did, how it would be possible (as in the case of the church fathers) to be both a Christian and a Roman at the same time. His question centered on how it could be possible (as in Antiquity) to be wholly Roman, that is pagan. He thus advocated a direct return to the pre-synthetic thought of Antiquity and not via early Christian thought.

The Humanists thus sought the value of Antiquity in itself - they did not regard it as a preliminary step to Christendom, as did the Christian synthetic thought of the Middle Ages. The medieval men took pagan antiquity to their bosom and Christianised it. The humanists put Antiquity back into its own milieu to act anew as a source of inspiration for the sixteenth century.

\subsubsection{Renaissance}

A second trend within the secular oriented currents of the sixteenth century was the Renaissance in Italy. Hyma (1951) sketches the general background and discusses its influence on Luther and Calvin in particular. As a general introduction the work of Estep (1986) also contains valuable information.

\section{- The beginning of secularisation}

The word renaissance implies rebirth. Not rebirth through the power of God's Spirit, as Christians usually believed. This original biblical 
word was now secularised to attain a quite different meaning: rebirth through the power of human reason.

The renaissance thinkers thus revealed little appreciation for the past and asked all attention for the present and the future. Wellknown representatives of this trend were Copernicus (d.1543), Bruno (d.1600), Kepler (d.1630) and Francis Bacon (1561-1626).

There can be no doubt that the renaissance thinkers' intention was the emancipation from religious (ecclesiastical) and secular (political) repression and the secularisation of life. The revival of classical antiquity was for them not an end in itself (as it was for the earlier repristinatory movements already discussed), but a mere means towards the final end of complete human autonomy. The Renaissance was the beginning of the secularisation of European culture.

\section{- Different from the Reformation}

The idea that the Reformation and Renaissance were parallel movements, inspired by one Christian humanist tradition, is therefore open to serious doubt (cf. Van der Walt, 2008). Klapwijk (1991:126127) writes:

Qua spirit and starting point Renaissance and Reformation were antagonists. Was Greco-Roman antiquity not the main source of inspiration for the artists of the Renaissance, while the Reformers drew from the fountain of holy Writ? ... Renaissance and Reformation went separate ways. The one movement seized upon the creative spark of poetic imagination or relied on the guidance provided by the light of natural (sometimes even deified) reason; the other movement built upon faith (sola fide) and sought to walk in the light of the biblical Wordrevelation (sola Scriptura).

Fowler (2008:20) says the same: "Where the Renaissance was founded in faith in the rationality and creativity of the human person, the Reformation was founded in faith in the Word of God."

\subsubsection{The link between Humanism and Renaissance}

The third trend within the secular or anti-biblical, anti-synthetic thought (also primarily in Italy and later in France) was the combination of Humanism and the Renaissance. This link was easy to establish, because both these trends were inclined to anti-synthetic, secular thought. Added to this was the fact that the disappointment within Humanism was responsible for the gradual relinquishing of the motif of repristination. Valla (d.1457) consoled himself with the 
idea that the greatness of Rome lay in its language, so that Humanism turned into being a linguistic movement with its aim the maintenance of Latin. However, the fact that it wanted to uphold a dead language at the expense of the vernaculars received little support from the masses.

Important representatives of this movement (also called florentine Humanism) were inter alia Marsilius Ficino (1433-1499), Giovanni Pico della Mirandola (1463-1494), Leo Hebraeus (1460-1527), A.M. de Montaigne (d.1592) and B.P. Charoon (d. 1603).

\subsubsection{Possible influences on the sixteenth-century Reformation}

Hall (1956:7) attempts the following division of this later Humanism into five types: a renaissance Humanism, resulting from the strong influence of Italian art circles; a Platonising-mystical type; a type featuring philology as important, because of the literary reawakening (Erasmus and others); a type in which the study of Roman law was emphasised; and lastly french Humanism, as represented particularly by printers and booksellers. According to him both the Reformation and Calvin were inspired especially by the third group followers of Erasmus.

\section{- A new type of exegesis}

According to De Vogel (1968:12) this specific group gave rise to a historic-philological method, according to which there was not only a return to the original sources, but also a reverent attitude towards these antique texts. This historical awareness and the effort to be objective towards an antique source and to let it speak for itself, was a novelty in those days. This same attitude was assumed by the sixteenth-century reformers towards the Holy Scripture. It was an enormous step forward when most of them (especially Calvin) broke with the centuries-old allegorical exegesis of the Scriptures. This method used to be an important means for achieving a synthesis between biblical and all sorts of pre-Christian philosophies.

\section{- Influence of stoic philosophy}

A typical characteristic of the third group was furthermore that it sought a new ethic in antiquity, especially in the Roman Stoa (particularly Seneca), since it could not endure the corruption of the church anymore. This resurgence of Stoic thought during Humanism and the Renaissance has become a well-known fact. Bouwsma (1975) writes fascinatingly on the various reasons why the Stoa had 
such an attraction. It is not at all surprising that Calvin's first work was a commentary on Seneca's De Clementia (1532).

\section{- Reasons for the links}

Although like De Groot $(1955: 24,29)$ justifiably says that Humanism and the Renaissance were religiously speaking radically antithetical towards the Reformation, he also points out that the Reformation did not immediately see through Humanism in all its implications. He proposes the following reasons for this (cf. De Groot, 1955:27-29):

- No matter how enthusiastically the Humanists devoted themselves to the study of the literary heritage of classical literature, they could not break away completely from the Christian tradition.

- As the major struggle of the Reformation was against the Catholic Church, and also Humanism (out of other considerations) was tired of church supremacy and scholastic theology, the reformers tended to be sympathetically inclined towards Humanism.

- Furthermore, the men of the Reformation were profoundly aware of the fact that they were indebted to the scientific labour of the Humanists. Mention has already been made of their historic-philological hermeneutic methods. To be remembered also is Erasmus' pioneering work as regards the New Testament and Reuchlin's regarding the Old Testament.

- Many of the reformers and their co-workers (including Calvin) had their scholarly apprenticeship in Humanist schools and could never entirely free themselves of these influences.

All the reformers, however, some sooner and some later, broke their initial links with Humanism (cf. Dankbaar, 1978). Both movements, as a result of religious differences, eventually assumed their own stand and took their own course.

\subsection{Christian anti-synthetic thought: the uniqueness of the Reformation}

The Reformation was, next to leftist anti-synthetic thought (Humanism, Renaissance and a combination of the two), the second most important trend at the beginning of the new or modern epoch. The reformers learned a great deal from the pre-Reformation and other already mentioned trends, even if this was mostly negative. They realised that a new future cannot be constructed on a return to the past (different trends prior to the Renaissance) or by rebirth through 
one's own power (the aim of Renaissance thinkers), but only through a renewed turning to the God of the Scriptures.

The reformers, for example, accepted much from Augustine. It was, however, not the Augustine of the Middle Ages, nor Augustine the Christian Roman of early Humanism, but Augustine the church father, who could serve as a guide back to the Word of God.

The reformers thus thought anti-synthetically from a completely different motive than Humanism and Renaissance. They wanted to restore again the Word of God to its rightful place. The Reformation was thus not primarily a philosophical trend (although it is not without meaning for Christian philosophy), but (like the pre-Reformation) it revealed a religious character in the positive Christian sense.

\section{Retrospect and summary}

The aim of the preceding pages was to offer a broad framework within which the specific place and contribution of the Reformation, and more specifically John Calvin, could be properly understood.

\subsection{A very complex time}

The intellectual décor painted above, revealed at least the following:

- it was a time of dissatisfaction with the past;

- it was also a period of rapid change, insecurity and uncertainty, both spiritually and in many other areas;

- in order to find new direction for European culture, different trends (like Platonism, Aristotelian Thomism, Stoism and even Epicurianism and scepticism), after centuries of dormancy, were revived. Prior to the Renaissance, therefore, a strong tendency towards repristination dominated;

- at the break of dawn in a new era in western cultural history all these spiritual currents fought for the heart of the European man;

- the sixteenth-century Reformation thus appears at a time of Sturm und Drang - a very complex time.

The basic question, however, was what or who is to be regarded as normative for the future. Should the past be the guide (e.g. repristination in pre-Reformation and early humanism); or should the present be the norm (e.g. the Renaissance); or should the future be the directive (e.g. the utopian dreams of the Anabaptists)? Should philo- 
sophies (like Scotism, Platonism or Stoicism) show the way or is obedience to God's Word (e.g. Calvin and the other reformers) the only trustworthy directive for life? Because the sixteenth century was basically a struggle between these different spiritual or normative directions, it was also a decisive epoch in Western history.

\subsection{A decisive epoch}

The Reformation came into being at a time in which ways split. The sixteenth century was the end of the important role that Christianity had played for about a thousand years (500-1500) and the beginning of the secularisation of the Western world. Christian (synthetic) thought had to make room very quickly for secular anti-synthetic thought, which would henceforth play the leading role in western civilisation.

This epoch thus brought about the end of a more than thousandyear old alliance (from early Christian thinkers onwards) between Christendom and pagan thought. From now on the ways would diverge. In spite of the fact that great scholars like Newton and Boyle still wanted to think as Christians, it became the era of the dying Christendom (at least in so far as it concerns Christian influence in the fields of science and culture in general outside the narrow confines of the church) and of a resurging paganism. The new secular way of thinking tried briefly, still uncertain on its own legs, to return for inspiration to antique Greek and Roman thought. After repristination had proven not to be fruitful, it proceeded on its own to engulf the new western world.

By the end of the 17th century, the force of the Renaissance, refined and consolidated in the Enlightenment, emerged as the dominant force shaping European culture. The successors of the Reformation operated on the sidelines ... culturally marginal (Fowler, 2008:20).

\subsection{The uniqueness of the Reformation}

From the preceding the unique character of the Reformation amidst all the other spiritual trends clearly emerged. I agree with Vollenhoven $(2005 a: 74,79)$ who emphasised that the essential meaning of the sixteenth-century Reformation did not reside in "it being a historical change in the horizontal dimension of time, but a religious change in the vertical dimension of the relationship towards God an his law"; it should not be regarded as a "conversion to the past", or a "reaction to the past", or "an idealisation of the future", but a "con- 
version towards God and his Word". The Reformation thus repeated and re-emphasised anew, after many centuries, the total sovereignty of God and the absolute authority of his Word.

When philosophy is guided by God's Spirit and directed by faith in God's Word, one's perspective is opened to the infinite. Klapwijk (1987:17) asks, however, if Calvin's Christian philosophy does not nullify the role of human reason? His answer is that Calvin did not ban the intellect, but removed an autonomous reason from its throne.

\subsection{Not the full picture}

There can be no doubt that this fundamental religious direction of the sixteenth-century Reformation was also shared by John Calvin. Such an assessment, however, does not yet provide a complete picture of this great reformer. The traditional sola Scriptura, sola fide, sola gratia and soli Deo gloria may encourage such an incomplete picture of Calvin.

The crucial, remaining question is whether Calvin succeeded fully and consistently to allow this basic biblical-Christian direction to determine the content of his thought. (Cf. again the distinction between direction and structure or philosophical trend and type under 1.2.) This is such a vital issue in Calvin research that it deserves detailed treatment in a separate article.

\section{List of references}

ASHLEY, L.A. 1962. Contributions to the protestant reformation by preReformation reformers. Lexington: College of the Bible. (Ph.D. thesis.)

BOHATEC, J. 1950. Budé und Calvin. Graz: Bolhaus.

BOUWSMA, W.J. 1975. The two faces of humanism: Stoicism and Augustinianism in renaissance thought. (In Oberman, H.A. \& Brady, T.A., eds. Itinerarium Italicum: the profile of the Italian Renaissance in the mirror of its European transformations. Leiden: Brill.)

BOUWSMA, W.J. 1988. John Calvin, a sixteenth-century portrait. New York: Oxford University Press.

BRIL, K.A. \& BOONSTRA, P.J., reds. 2000. D.H. Th. Vollenhoven: schematische kaarten; filosofische concepties in probleemhistorisch verband. Amstelveen: De Zaak Haes.

DANKBAAR, W.F. 1978. Hervormers en humanisten. Amsterdam: Ton Bolland.

DE GROOT, D.J. 1955. De reformatie en de staatkunde. Franeker: Wever.

DE VOGEL, C.J. 1968. Het humanisme en zijn historisch achtergrond. Assen: Van Gorcum.

ESTEP, W.R. 1986. Renaissance and reformation. Grand Rapids: Eerdmans.

FOWLER, S. 2008. Living worldviews. Melbourne: Amani Educational Services. 
GAMBLE, R.C. 1994. Current trends in Calvin research, 1982-1990. (In Neuser, W.H., ed. Calvinus Sacrae Scripturae Professor: Calvin as confessor of Holy Scripture. International Congress on Calvin Research, 20-23 Aug. 1990. Grand Rapids: Eerdmans. p. 91-112.)

GANOCZY, A. 1969. La bibliotèque le l'Académie de Calvin: le catalogue de 1572 et ses enseignements. Genève: Librairie Droz.

GANOCZY, A. 1987. The young Calvin. Trans. by D. Foxgrover \& W. Provo. Philadelphia: Westminster.

GANOCZY, A. \& MÜLLER, K. 1981. Calvins handscriftliche Annotationen zu Chrysostomus: ein Beitrag zur Hermeneutik Calvins. Wiesbaden: Steiner Verlag.

GRÜNDLER, Q. 1961. Thomism and Calvinism in the theology of Girolamo Zanchi (1516-1590). Ann Arbor: University Microfilms.

HALL, B. 1956. John Calvin, humanist and theologian. London: Historical Association.

HYMA, A. 1951. Renaissance and Reformation. Grand Rapids: Eerdmans.

KLAPWIJK, J. 1987. Johannes Calvijn: in de greep van de Geest. (In Klapwijk, J. Kijken naar kopstukken. Amsterdam: Buijten \& Schipperheijn. p. 14-17.)

KLAPWIJK, J. 1991. John Calvin (1509-1564). (In Klapwijk, J., Griffioen, S. \& Groenewoud, G., eds. Bringing into captivity every thought: capita selecta in the history of Christian evaluations of non-Christian philosophy. Lanham: University Press of America. p. 123-141.)

KLAPWIJK, J. 1994. Calvin over wijsbegeerte: oefening in ootmoedigheid. (In Zijlstra, A. \& Doornebal, R.J.A., reds. Christelijke filosofie in beweging. Amsterdam: Buiten \& Schipperheijn. p. 92-100.)

KRISTELLER, P.O. 1953. The classics and Renaissance thought. Cambridge: Harvard University Press.

NAUTA, D. 1976. Stand der Calvinforschung. (In Neuser, W.H., ed. Calvinis theologus. European Congress on Calvin's Research, 16-19 Sept. 1974. Neukirchen-Vluyn: Neukirchener Verlag. p. 71-84.)

NEUSER, W.H. 1982. International Calvin research. (In Van der Walt, B.J., ed. Calvinus reformator: his contribution to theology, church and society. Potchefstroom: Institute for Reformational Studies. p. 1-7.)

NIESEL, W. 1980. The theology of Calvin. Trans. by H. Knight. Grand Rapids: Baker.

OBERMAN, H.A. 1966. Forerunners of the Reformation. New York: Holt, Rinehart \& Winston.

OBERMAN, H.A. 1967. The harvest of medieval theology. Grand Rapids: Eerdmans.

OBERMAN, H.A. 1974a. Headwaters of the Reformation. (In Oberman, H.A., ed. Luther and the dawn of the modern era. Leiden: Brill.)

OBERMAN, H.A. 1974b. The shape of late medieval thought. (In Oberman, H.A., ed. The pursuit of holiness in late Medieval and Renaissance religion. Leiden: Brill.)

OBERMAN, H.A., ed. 1975. Itinerarium Italicum: the profile of the Italian Renaissance in the mirror of its European transformations. Leiden: Brill.

OBERMAN, H.O. 1994. Initia Calvini: the matrix of Calvin's reformation. (In Neuser, W.H., ed. Calvins Sacra Scripturae Professor: Calvin as confessor of Holy Scripture. Grand Rapids: Eerdmans. p. 113-154.)

PARKER, T.H.L. 2007. John Calvin: a biography. Louisville: John Knox Press. 
PARTEE, C. 1974. The revitalization of the concept of a "Christian philosophy" in Renaissance humanism. Christian scholars review, 3(4)360-369.

PARTEE, C. 1977. Calvin and classical philosophy. Leiden: Brill.

REID, W.S. 1978. The cultural setting of the reformation. Word and Action, 19(194):13-15, Oct.

REID, W.S., ed. 1982. John Calvin: his influence in the western world. Grand Rapids: Zondervan.

REUTER, K. 1963. Das Grundverständnis der Theologie Calvins unter Einbeziehung ihrer geschichtliche Abhängigkeiten. Neurkirchen: Neurkirchener Verlag.

SAXER, E. 1984. Hauptprobleme der Calvinforschung - Forschungsbericht: 1974-1982. (In Neuser, W.H., ed. Calvinus ecclesiae Genevensis custos. International Congress on Calvin Research, 6-9 Sept. 1982. Frankfurt am Main: Peter Lang. p. 93-112.)

SELDERHUIS, H.J. red. 2008. Calvijn handboek. Kampen: Kok.

SELDERHUIS, H.J. 2009. John Calvin: a pilgrim's life. Downers Grove: IVP Academic.

VAN DER WALT, B.J. 1979. Die denkdekor van die Reformasie met spesiale verwysing na Calvyn. Potchefstroom: Instituut vir Reformatoriese Studie.

VAN DER WALT, B.J. 1991. The intellectual décor of the Reformation with special reference to Calvin. (In Van der Walt, B.J. Anatomy of reformation: flashes and fragments of a reformational worldview. Potchefstroom: Institute for Reformational Studies. p. 209-256.)

VAN DER WALT, B.J. 2008. Renaissance and Reformation: contemporaries but not allies. (In Van der Walt, B.J. Anatomy of reformation. Potchefstroom: Institute for Contemporary Christianity in Africa. p. 201-208.)

VOLLENHOVEN, D.H. Th. 2005a. De probleemhistorische methode en de geschiedenis van de Wijsbegeerte. Red. door K.A. Bril. Amstelveen: De Zaak Haes.

VOLLENHOVEN, D.H. Th. 2005b. The problem-historical method and the history of philosophy. Ed. by K.A. Bril. Trans. by J. de Kievit, J. Francke, J.G. Friesen \& R. Sweetman. Amstelveen: De Zaak Haes.

VOLLENHOVEN, D.H. Th. 2005c. Isagoge philosophiae/Introduction to philosophy. Ed. by J.H. Kok \& A. Tol. Sioux Center: Dordt College Press. (Bilingual edition.)

WENDEL, F. 1963. Calvin: the origins and development of his religious thought. Trans. by P. Mairet. London: Collins.

YOST, J.K. 1965. The humanism of the English reformers, 1525-1555: a study in Renaissance humanism. Ann Arbor: University Microfilms.

\section{Key concepts:}

Calvin, J.

Reformation (protestant)

sixteenth century

spiritual trends 


\section{Kernbegrippe:}

Calvyn, J.

geestestromings

Reformasie (protestantse)

sestiende eeu 
